\begin{tabular}{|l|l|l||}
\hline \multicolumn{2}{|c|}{ PublisherInfo } \\
\hline \hline PublisherName & $:$ & BioMed Central \\
\hline \hline PublisherLocation & $:$ & London \\
\hline \hline PublisherImprintName & $:$ & BioMed Central \\
\hline \hline
\end{tabular}

\title{
Making way for repair
}

\begin{tabular}{|l|l|l||}
\hline \multicolumn{2}{|c|}{ ArticleInfo } \\
\hline \hline ArticleID & $:$ & 3873 \\
\hline \hline ArticleDOI & $:$ & $10.1186 /$ gb-spotlight-20001227-01 \\
\hline \hline ArticleCitationID & $:$ & spotlight-20001227-01 \\
\hline \hline ArticleSequenceNumber & $:$ & 310 \\
\hline \hline ArticleCategory & $:$ & Research news \\
\hline \hline ArticleFirstPage & $:$ & 1 \\
\hline \hline ArticleLastPage & $:$ & 2 \\
\hline \hline & & RegistrationDate : 2000-12-27 \\
ArticleHistory & $:$ & OnlineDate $\quad$ 2000-12-27 \\
\hline \hline ArticleCopyright & $:$ & BioMed Central Ltd2000 \\
\hline \hline ArticleGrants & $:$ & \\
\hline \hline ArticleContext & $:$ & 130591111 \\
\hline \hline
\end{tabular}




\section{William Wells}

Email: wells@biotext.com

In the 21/28 December Nature Downs et al. suggest that phosphorylation of budding yeast histone $\mathrm{H} 2 \mathrm{~A}$ in response to radiation damage loosens up chromatin to allow the entry of repair proteins (Nature 2000, 408:1001-1004). They mutate the carboxyl terminus of H2A to replace a serine, whose phosphorylation is dependent on the DNA-damage-induced kinase Mec1, with an alanine. The resulting strain is sensitive to agents that induce double-strand breaks (DSBs), but not to ultraviolet light or mutagens that affect a single DNA strand. Transcriptional responses to DNA damage, checkpoint delays, and repair by homologous recombination are not affected by the mutation, but DSB repair by non-homologous end joining (NHEJ) is defective. A serine to glutamic acid substitution that mimics the phosphorylated $\mathrm{H} 2 \mathrm{~A}$ results in plasmids that are topologically more relaxed, and regions of DNA between individual nucleosomes that are more susceptible to degradation. Thus the Mec1-dependent phosphorylation of H2A may facilitate NHEJ by decondensing chromatin to allow repair proteins better access to the DNA.

\section{References}

1. Nature, [http://www.nature.com/nature/]

2. Crystal structure of the nucleosome core particle at 2.8 A resolution. 